\title{
Editorial: Publishing in Studies in Philosophy and Education
}

\author{
Gert Biesta
}

Published online: 17 December 2009

(C) Springer Science+Business Media B.V. 2009

Academic journals perform a double role. On the one hand they represent a particular field or area of scholarship and research; on the other hand they intervene in the field by representing the field in a particular way and by being open to contributions that challenge existing definitions of what the field is about. Sometimes such contributions challenge the boundaries of the field in an explicit manner, but more often than not such shifts occur over time and only gradually open up new areas of scholarship and research. Particularly in the humanities and social sciences such shifts are less of a revolutionary and more of an evolutionary nature (see Toulmin 1972). Journal editors occupy an interesting position in relation to this. Since they generally rely on unsolicited manuscripts and the outcomes of peer review, they have limited opportunity to steer a field in a particular direction. In this regard their role is more that of a facilitator and intermediary, albeit that there is some scope, particularly through special issues, to highlight or promote particular areas of scholarship.

Whereas some academic journals focus more narrowly on a particular area and, within this, sometimes also on a particular approach within the field, Studies in Philosophy and Education has, from its inception in 1960 onwards, always had the explicit ambition not to be the expression of any one philosophical or theoretical school or cultural tradition. Being an international journal, Studies in Philosophy and Education always also has had the ambition to be inclusive of a wide range of different approaches to, and understandings of 'the field.' One understanding of the field sees the philosophical engagement with educational issues as a form of applied or practical philosophy. Hence the starting point for educational philosophy lies in the discipline of philosophy, which is also thought to set the standards for what counts as 'good' or 'proper' philosophy of education. Such a view is particularly prominent in the Anglo-American world and has played an important role in the establishment of the study of education at university level (see Peters 1966; Tibble 1966).

But the Anglo-American 'construction' of the study of education in which this particular conception of philosophy of education has its place, is by no means the only way in

G. Biesta $(\bowtie)$

The Stirling Institute of Education, University of Stirling, Stirling FK9 4LA, Scotland, UK

e-mail: gert.biesta@stir.ac.uk 
which philosophical and theoretical work in education can be conducted and has been conducted. In continental Europe, and particularly in the German speaking world, the field of educational studies has had a different history (see, for example, Keiner 2002). This has resulted in a different configuration of the field and a different engagement with and position for theoretical and philosophical work. One important difference that is relevant for an international journal such as Studies in Philosophy and Education is that in this continental 'construction' of the field the engagement with philosophical and theoretical ideas in education is not so much seen as a form of applied or practical philosophy but rather as a form of educational theorising in which philosophical resources are being used (see, for example, Mollenhauer 1972; König 1975; Benner 2005). An important difference between the two approaches is that whereas scholars working in the Anglo-American 'construction' would generally ask philosophical questions about education, those working within the continental 'construction' would ask educational questions about education and would use philosophical and other theoretical resources to address these questions. (It is important to bear in mind, of course, that what would count as an educational question is itself a matter of ongoing discussion and debate; see, for example, Wulf 1978, for an overview of the early history of such discussions.)

Both approaches are legitimate ways of connecting philosophy and education, and it is important that both approaches are represented in a journal such as Studies in Philosophy and Education. In this regard it is not insignificant, of course, that the journal is called Studies in Philosophy and Education, and not Studies in Philosophy of Education. But particularly for a journal that almost exclusively publishes work in the English language it is important to make prospective authors aware of the different constructions of the field of educational studies and of the different positions of philosophical work within them. From an Anglo-American perspective there is, perhaps, also something to learn from the continental approach-something that may well be important, at least strategically, in a time when many involved in philosophy of education feel that the legitimacy of their work is being ignored or even threatened by wider educational research, policy and practice communities. To overstate the issue a little: if philosophy of education insists on asking philosophical rather than educational questions about education, it may well be more difficult for others within the educational field to recognise the relevance and importance of such questions. I am, of course, overstating the issue by putting it in this way, as much work that locates itself within the Anglo-American 'construction' of philosophy of education engages with central and important educational issues.

As an editor, however, I do come across work that sometimes dwells a little too much in philosophy and either presents education as an 'afterword' - as a kind of obligatory last section called 'implications for education —or pairs sophisticated and critical philosophical analysis with rather common sense and unproblematised views about educational processes and practices. In those cases I do think that it would be desirable to create a better balance between the philosophical and educational. This is not only important in order to make clear that philosophical work in education is as critical in its philosophical outlook as it is in its engagement with education. It can also help to give educational issues and concerns a more prominent place which, in turn, might help to engage more directly with the concerns of other scholars and researchers in education, and with educational policy makers and practitioners.

This relates to two further observations I wish to make. One has to do with the fact that much philosophically inspired work in education tends to focus on engagement with original philosophical work and philosophical commentaries on this work. To do so is, of course, an important aspect of philosophical scholarship, but one of the less desirable by- 
effects of such an approach is that work from other philosophers of education is sometimes neglected. The danger here is not only that of reinventing the wheel rather than building upon existing work. It may also have a potentially negative impact on the development of the community of those working in philosophy and education because of the fact that original and important work from members of this community gets less used and cited than the so-called 'original' philosophical sources. Again, therefore, a better balance might be struck if those working in the field would-perhaps as a matter of principle-make sure that they engage both with the 'original sources' from philosophy and with the original voices within their own community.

To think of the field as a community is not to suggest that univocity would be more desirable than plurivocity. The contrary is the case. A healthy field needs a plurality of voices, views, and positions and needs dissensus as much as it needs consensus. But it is important to be aware of the fact that a field such as philosophy of education-in its many different manifestations-only exists because of the ongoing work of many, both those contributing their ideas, insights and scholarship and those facilitating the exchange and development of such work through teaching, symposia, conferences and academic journals. One of the most invisible roles within this constellation is that of journal reviewers. They do, however, perform an indispensable role for the field, not only as gatekeepers but perhaps even more through their formative contributions, their encouraging feedback and suggestions that generally tend to improve the quality of what gets eventually published. To acknowledge these contributions is an important way to honour the work that is done to keep the community of those working at the intersection of philosophy and education into existence and to secure its future.

Acknowledgment I would like to thank Ann Chinnery for her feedback on an earlier version of this text.

\section{References}

Benner, D. (2005). Allgemeine Padagogik (5th ed.). Weinheim/Munchen: Juventa.

Keiner, E. (2002). Education between academic discipline and profession in Germany after World War II. European Educational Research Journal, 1(1), 83-98.

König, E. (1975). Theorie der Erziehungswissenschaft. Band 1. München: Wilhelm Fink Verlag.

Mollenhauer, K. (1972). Theorien zum Erziehungsprozess. München: Juventa.

Peters, R. S. (1966). The philosophy of education. In J. W. Tibble (Ed.), The study of education (pp. 59-90). London: Routledge and Kegan Paul.

Tibble, J. W. (1966). The development of the study of education. In J. W. Tibble (Ed.), The study of education (pp. 1-28). London: Routledge and Kegan Paul.

Toulmin, S. (1972). Human understanding, volume 1: The collective use and development of concepts. Oxford: Clarendon Press.

Wulf, Chr. (1978). Theorien und Konzepte der Erziehungswissenschaft. München: Juventa. 